\title{
IMPROVEMENT OF SOME ESTIMATIONS RELATED TO THE REMAINDER IN GENERALIZED TAYLOR'S FORMULA
}

\author{
M. MATIĆ
}

Abstract. We prove an inequality of Grüss type and using it we strictly improve some estimations of the remainder in generalized Taylor's formula obtained via harmonic sequence of polynomials.

Mathematics subject classification (2000): 26D15, 41A58.

Key words and phrases: Taylor's expansion, harmonic polynomials, Grüss type inequalities.

\section{REFERENCES}

[1] M. Matić, J. Pečarić and N. Ujević, On new estimation of the remainder in generalized Taylor's formula, Math. Inequal. Appl. 2 (3) (1999), 343-361.

[2] S.S. Dragomir, New estimation of the remainder in Taylor's formula using Grüss' type inequalities and applications, Math. Inequal. Appl. 2 (2) (1999), 183-193.

[3] M. Abramowitz and I. A. Stegun (Eds), Handbook of Mathematical Functions with Formulas, Graphs, and Mathematical Tables, National Bureau of Standards, Applied Mathematics Series 55, 4th printing, Washington, 1965

[4] J. E. Pečarić, F. Proschan and Y. L. Tong, Convex Functions, Partial Orderings, and Statistical Applications, Academic Press, 1992. 